\title{
Persistent farmland imaginaries: celebration of fertile soil and the recurrent ignorance of climate
}

\author{
Oane Visser $^{1}$ (D) \\ Accepted: 12 September 2020 / Published online: 15 October 2020 \\ (c) The Author(s) 2020
}

\begin{abstract}
This article looks at how imaginaries of land and climate play a role in farmland investment discourses and practices. Foreign farmland investors in the fertile black earth region of Russia and Ukraine have 'celebrated' soil fertility while largely ignoring climatic factors. The article shows a centuries-long history of outsiders coming to the region lured by the fertile soils, while grossly underestimating climate which has had disastrous implications for farm viability and the environment. Comparisons with historical and contemporary literature on other regions (e.g. the US prairies and North Africa) suggest that the underestimation of climatic risks by newcomers is remarkably prevalent in resource frontiers.
\end{abstract}

Keywords Land imaginaries $\cdot$ Ignorance $\cdot$ Soil $\cdot$ Farmland investment $\cdot$ Climate

The Russian black earth soil is more valuable than gold (statement by renowned soil scientist Vasily V. Dokuchaev in the late nineteenth century). ${ }^{1}$

The Company holds ownership of an extensive land bank of first-class soil (...). The soil type, Chernozem or "black earth", has a black color and contains a high percentage of humus.... It usually has great depth, over 1 meter, and exhibits a clay like structure which facilitates agricultural field works and is also favorable for retaining water. (website of Swedish-owned farmland company 'Black Earth Farming' operating in Russian and Ukraine from 2005-2017). ${ }^{2}$

\section{Introduction}

This article examines the remarkable historical persistence of farmland imaginaries in the face of opposing evidence. In particular, it investigates how favourable imaginaries of the soil by farmland investors can sideline important climatic factors, with potentially far-reaching implications for farm operations and the environment. It will do so based on the

Oane Visser

visser@iss.nl

1 International Institute of Social Studies (ISS), The Hague, of Erasmus University Rotterdam, Rotterdam, The Netherlands case of the black earth, which is widely considered the most fertile soil in the world. Some of the world's largest stretches of black earth (chernozem) $)^{3}$ can be found in southern Russia and most of Ukraine. Since the mid-2000s, this black earth area, the agricultural heartland of the former Soviet Union, has experienced a rapid rise of farmland investment in the context of the global farmland rush (or global 'land grab'). The accounts of farmland investors flocking to this region in search of 'untapped' farmland have been littered with praise of 'the black earth, millions of hectares of ultra-fertile agricultural land' (The Local 2009), with soil that is 'legendary' 4 and constitutes the 'best soil of the world' (Kuns et al. 2016; Visser 2017), a 'dream soil' (The Local 2009), that farmers in the in the West 'would kill for'. There is much scientific basis for praising the black earth, as there is little doubt that it is one of the most-if not the most-fertile soil(s) on earth, with many favourable features potentially allowing for high yields (Moon 2013). Also referred to as chernozemic soils, these soils can produce high agricultural yields due to their high humus content and high percentages of phosphoric acids, phosphorus and ammonia.

\footnotetext{
1 Dokuchaev (1994).

2 Author's database. Statement taken from website (https://blackearth farming.com).

${ }^{3}$ While Russia and Ukraine have the largest territories with black earth within Eurasia, the chernozem belt stretches from Kazakhstan to Serbia. Also in North and South America, large areas of chernozem (mollisols in the current USDA soil taxonomy) can be found.

4 www.brookings.edu/blogs/future-developmen t/posts /2016/03/03-farm-land-reform-ukraine-strubenhoff.
} 
Despite the huge benefits of chernozem for agriculture, the performance of foreign farmland investors in Russia and Ukraine has been below projections, and has in many cases been outright disappointing (cf. Kuns et al. 2016; Visser 2017). Whereas the foreign farmland companies initially generated a lot of investment and had high stock valuations, reflecting high hopes for their performance, they appeared to operate at a loss, often for many years in a row, and two of them even had to delist. The first of the two main questions in this article is: How can this gap between projected and real life performance (of foreign farmland investments) in the black earth region be explained? This article argues that the investor narratives celebrating the black earth soil not only stirred up high expectations, but also contributed to the dismal performance. ${ }^{5}$ While the fixation on the soil was an effective device to 'sell' the business case for global farmland investment in the region, it also blinded the farmland companies themselves. Relevant aspects of farming, such as the run-down rural infrastructure and volatile weather, were downplayed, sidelined, or completely ignored, both in terms of discourses and farm strategies, and operations. It will be shown that amongst a wide range of factors that fell by the wayside in farmland investors' assessments due to the fixation on the soil, the ignorance of climate was particularly striking and arguably the one with the most far reaching negative repercussions for the profitability of their farms.

The narratives of these contemporary farmland investors are only the latest incarnation of long-standing farmland imaginaries of the black earth. This article will show that there is a remarkable continuity in the 'celebration' of the black earth. Even since the southward and eastward expansion of the Tsarist Russian empire in the late seventeenth and eighteenth centuries, the ignorance or misunderstanding of climate has prevailed (Wheatcroft 1977; Wheatcroft and Davies 1994; Moon 2013). This ignorance has persisted despite a long record of disappointing farming results by newcomers in the Soviet and pre-Soviet era that resulted from, or were reinforced by, such ignorance. The abovementioned land imaginaries thus hindered newcomers in effectively adapting to agro-climatic circumstances. The article will subsequently ask the second main question: How could such land imaginaries persist, and climate continuously be ignored, in the face of meagre farm performance, and growing evidence that was at odds with prevailing land imaginaries?

By addressing the two questions above, this study demonstrates how land imaginaries can take on a life of their own, have far reaching implications for farm operations and, more generally, affect how people relate to land. In addition, it examines what contributes to the resilience of farmland imaginaries in the face of opposing evidence. More broadly,

${ }_{5}$ Amongst other factors (see below). in line with Sippel and Visser (2020) it argues that in examining resource making projects and resource frontiers, it is imperative to pay attention to the (often overlooked) issues of representation and knowledge making (and obscuring), particularly as expressed in farmland imaginaries.

This article aims to build on, and integrate, social science literature on how nature (and land in particular) is made into a natural resource (Richardson and Weszkalnys 2014; Li 2014), and financial asset (Ouma 2016; Visser 2017), the literature on farmland investment (e.g. Visser et al. 2012; Wolford et al. 2013), and environmental histories (e.g. Worster 1979; Moon 2013, 2020), in particular those of frontier (steppe) regions in settler colonies (Worster 1979; Cronon 1991; Moon 2020) but also to some extent in the global South (Davis 2007, 2011). Studies on assembling the various aspects of farmland into a financial asset have not yet paid much attention to the historical dimension of this phenomenon, as Ouma (2016) observed. This article attempts to correct this gap by taking a historical approach to farmland assemblage in a specific region, building on studies of the historical dimensions of contemporary investment and commodification in natural resources (Edelman and León 2013) and social-environmental histories of geographical regions (Worster 1979; Cronon 1991; Moon 2013, 2020).

This article is structured as follows. The next section lays out the conceptual framework and is followed by a section on the study region and methodology. The third section discusses the celebration of the black earth soil in the 2000s and in the past centuries. The fourth section examines investors' long-standing ignorance of climate in the black earth region, and the resulting negative repercussions. The fifth section asks how it has been possible that farmland imaginaries celebrating the chernozem, and ignoring climate, have been so persistent. To this aim it discusses other regional examples of long-standing ignorance or underestimation of climate by foreigners or outsiders from other continents. The final section concludes that the ignorance of climate seems to be remarkably common for farmland imaginaries in contemporary and historical resource frontiers worldwide.

\section{Theoretical framework: land imaginaries, asset making, and environmental history}

The way in which specific environments enable or obstruct farmland investment has not been researched in depth (Wolford et al. 2013). Agrarian studies mostly discuss biophysical environments only briefly to show how they are considered attractive for land acquisitions by investors (Goldstein 2016, p. 756). Virtually no studies 'have articulated how certain lands and ecologies are managed' once acquired by investors, and 'how that environmental management is underpinned by knowledge claims of land's suitability for 
consolidation and development' (ibid.). Following Li (2014), the question has shifted to how land can be constructed as suitable for, and consequently attract, investment (cf. Goldstein 2016, p. 756). So far, studies on the construction of farmland as an attractive investment have looked at investor narratives related to the property and territorial aspects of land, although occasionally they superficially touch upon ecological characteristics. For instance, it has been widely noted that the framing of lands as 'unused' or 'marginal' is a strategy of farmland investors and investor-oriented states to legitimize low-cost acquisition by investors (Visser et al. 2012; Wolford et al 2013). While research attention has focused on how investors' discourses purposefully use particular notions of land that benefit their business, they are also likely to be influenced by more implicit, unintentional notions of land. I contend, that the concept 'land imaginaries' is particularly useful to unearth those more hidden conceptions of land.

\section{Land imaginaries}

Actions of investors and other actors do not just result from the direct materialization of their economic or political interests. Interests and strategies on the one hand, and concrete farmland operations and transformations on the other, are mediated, and shaped, by land imaginaries, namely the notions of what land is, what it can or should do, and how humans can or should interact with it (Sippel and Visser 2020, cf. Jasanoff 2015 on socio-technical imaginaries more broadly). Such land imaginaries might not always be well articulated or consciously be used. Rather, land imaginaries constitute mental frameworks that inform practical engagements with land, implicitly and unreflexively (Davis 2011). Land imaginaries in this context refers to the taken-forgranted ideas that groups have developed about land, which also unconsciously influence uses of land. Such imaginaries might be reflected in narratives, financial indicators, maps, or websites. The implicit and un-reflexive nature that characterizes land imaginaries means that land imaginaries can also have unexpected or undesired implications. Much of the farmland investment literature sees farmland investors as opportunistically juggling notions of land in sophisticated ways to portray their investment most favourably to funders, states, and communities, in order to relentlessly further their investments. However, while investors influence society with their discourses on farmland, this article will show that investors themselves are also influenced by wider land imaginaries in society.

(Over)optimistic investor discourse based on shallow land imaginaries (e.g. imaginaries that ignore certain risks and subsequently overestimate the productivity of the farmland) may ensure funding and state support, but may also trap the investors themselves in high-risk, unfeasible investment projects (cf. Visser 2017). This article focuses on what imaginaries downplay or ignore by combining literature on farmland imaginaries with recent literature on ignorance (or 'agnotology') (Proctor 2008), particularly regarding the environment (ibid.; Uekötter and Lübken 2014). While investor discourses and land imaginaries can be modified, stretched, and embellished, the materiality of the land in question shows more resistance to human intervention. Whereas some studies on materiality focus predominantly on how the interaction between human and non-human actors creates (socio)natures, this article assumes that physical objects of nature exist or alter, both in interaction with humans, as well as independently (cf. Moon 2020, p. 22). From this perspective, even features of the natural environment that exist (largely) independently of human influences are perceived selectively (Hirsch 1995) through various senses or tools (cf. Cosgrove 2003). This selectivity influences how humans use and shape nature, and ultimately influences how humans are affected by it themselves.

\section{Resource and asset making}

In order to understand how the black earth soil became so central in the discourses of the investors operating in Russian and Ukrainian agriculture, this article draws on literature that studies how objects of nature become natural resources (Richardson and Weszkalnys 2014), and subsequently possible financial assets (Larder et al. 2017; Li 2014; Ouma 2016; Visser 2017). Although transnational farmland investments, especially those made by the financial sector, are considered increasingly footloose, virtual, and detached from the 'real' economy, the involvement of foreign and financial players in farmland investment necessitates taking the materiality of the investment object seriously. First, although recognizing that resource making as a human process is important, one should not ignore the limits set by the supposedly 'inanimate' natural environment to the cognitive and practical process of creating natural resources (Richardson and Weszkalnys 2014, p. 15). Indeed, as Richardson and Weszkalnys (2014, p. 15) contend, "the "becoming" of resources is now better understood in terms of the uses and possibilities that matter affords to us - what may be referred to as material agency or potentiality, which themselves depend on the historical, social and material environments which inform the constitution of the resource matter' (cf. Bennett 2010). Another important insight is that natural resources are 'a potent social category into which — and out of which — can slip those parts of the non-human world to which humans attached value' (Bridge 2009, p. 1218). When framed as 
resources, financial assets are assemblages that do not automatically have fixity. They can be reassembled and reconstituted into new arrangements (Li 2014; Visser 2017). Resource making does not only involve moving between non-resource and resource states. It is often a multi-faceted and multi-directional process (Visser 2017). ${ }^{6}$ At its core, resource making, and its advanced stage of asset making, is a process of abstraction (Richardson and Weszkalnys 2014, p. 13), including separation and simplification/reduction on both material and conceptual levels. These two aspects-separation and simplification-are very pronounced in the black earth imaginaries. In parallel to physical abstraction, the resource may also go through processes of homogenization and standardization (e.g. Richardson and Weszkalnys 2014, p. 13). The term '(farm) land' itself is already an abstraction (Li 2014). Before it is conceived of as 'land', it is ground, soil, pasture, earth et cetera (ibid).

\section{Environmental histories}

The academic literature on farmland investment has been strongly ingrained in critical agrarian studies, allowing broad comparisons across the centuries, especially regarding colonialism and the enclosure movement in England (cf. White et al. 2012). However, these were mostly quite general comparisons of a macro and global nature, not in-depth social and/or environmental histories of land investment in specific regions or countries. Given the lack in the literature on farmland investment of both attention for (1) materiality, in the form of the ecological/biophysical base and (2) the historical trajectories of farmland investment (and related imaginaries), engaging more with the field of environmental history is warranted. Environmental history deals with both the materiality of nature and its impact on humans; the impact of humans on nature; and human perceptions of nature (Worster 1977). This article mostly focuses on the first and the last aspects.

Drawing on environmental history is particularly appropriate for this study. The black earth region constitutes the birthplace of soil sciences. Further, the work of the pioneer-and arguably the founding father-of soil science, Dokuchaev, which is based on his expeditions to the chernozem region, also sparked the first ecological histories. However, both in the Soviet and post-Soviet period, studies of agriculture and farmland in the region have heavily prioritized a human centred analysis with political economy, property, and resistance, as prevalent concepts. The immense ideological and political transformations in the region, and

\footnotetext{
6 This is even more so the case for asset making, which can be seen as a more 'advanced' form of commoditization than resource making (Visser 2017).
}

the study of them, relegated the role of the environment to the margins of social science research. Rare exceptions of scholars giving nature a more central place analytically, are Smith (2014) and Wheatcroft (1977) (cf. Wheatcroft and Davies 1994). Besides these studies, this article builds on the milestone environmental history study of the black earth by David Moon (2013), which covers the period of the expansion of Russian agriculture into the steppes of the black earth region, in the Tsarist era. Overall, this study does not claim to offer an extensive environmental history by juxtaposing and comprehensively assessing different representations as an aim itself. This article solely approaches different historical and contemporary statements about land, including by environmental historians, as objects of analysis in a land imaginaries framework.

\section{Delving into the black earth area: regional focus and methodology}

This paper focuses on farmland investment in the chernozem area of Russia and Ukraine as a whole. As largely similar agro-ecological conditions feature throughout the region, it makes sense to have natural conditions, rather than country borders, determine the boundaries of the study. Further, due to the two countries' strongly interwoven history-during both Tsarist and Soviet periods - there are many similarities between them. They also feature very strong similarities in agrarian development in the post-Soviet era. Despite differences in the design and speed of their agricultural reforms and the land market, both countries simultaneously experienced the emergence of outside investors, who accumulated large landholdings and clustered multiple privatized collective and state farms into so-called agroholdings (Visser and Spoor 2011). Finally, many investors, at least until the 2014 conflict between Ukraine and Russia and the souring of relations between the two countries, saw the black earth as a single farmland investment region (with landholdings spread across the Ukrainian-Russian border) (Kuns et al. 2016). Agroholdings in Ukraine and Russia — both foreign and domestic - control very large, almost record-breaking landholdings, with up to several hundred thousand hectares and up to some 2000 employees (Visser et al. 2012; Kuns et al. 2016).

This article builds on primary and secondary literature, as well as multi-sited fieldwork. ${ }^{7}$ In-depth interviews and informal conversations were conducted with foreign and domestic farmland investors operating in Russia and Ukraine, mainly in the period 2013-2017. Interviewees were representatives

\footnotetext{
7 Some of the interviews and documents were collected during joint research with Brian Kuns (cf. Kuns et al. 2016).
} 
of Swedish, Danish, Dutch, German, UK, and US companies that had acquired farmland in Russia and/or Ukraine. Four of these companies (three Nordic and one German) were among Russia's top 25 largest landowners. The interviews were conducted in combination with farm visits as well as at company headquarters and business meetings in Western Europe. Document and web search of mostly Russian and English language sources included corporate documents of listed companies, business media, and historical sources, as well as visual analysis of contemporary sources such as photographs and videos. The term 'investor discourse', next to narratives by investors and managers/directors of investor-led farm companies, also encompasses the business press reporting on farmland investment and related consultants and intermediaries. The Ukrainian and Russian governments have largely facilitated farmland investment, employing land imaginaries resembling those of investors (Visser et al. 2012).

While going back in time to examine imaginaries of newcomers to the chernozem region, the nature of these newcomers and sources of this study change. The primacy of foreign companies amongst contemporary newcomers means that the sources consist of corporate documents and business press articles. In the Soviet era, it was foreign farm consultants and scientists who visited the region. These visitors' encounters with the black earth are investigated, based on the scant scholarly sources describing them (Ioffe and Nefedova 1998; cf. Smith 2014). In the pre-Soviet era, the newcomers consisted of US scientists working for the US Department of Agriculture (in the late nineteenth-early twentieth century), and Russian and Western scientists and explorers in the service of the expanding Russian empire (in the eighteenth and nineteenth centuries). For the pre-Soviet period, this article draws on the excellent environmental histories by Moon $(2013,2020)$ combined with the study of primary (digitalized) historical sources (e.g. Tooke 1800; Johnson 1843; Carleton 1900; Dokuchaev 2017).

\section{Celebrating the black earth}

'Let's go east' is the title of a thread on a web forum for German farmers, filled with glowing comments regarding investment in Russia. 'Let's go, lads,' one farmer wrote enthusiastically in 2012. 'The thawing permafrost soil is waiting for us (...). Get over there and farm as far as the horizon!' (Winter 2012). The vast areas of farmland, and the availability of abandoned land featured widely in the accounts of Western investors heading East (Visser et al. 2012). As the New York Times expressed it, there were 'millions of acres of untouched, pristine land' (Kramer 2008) awaiting investment. The idea of almost infinitely ongoing fields of fertile land for the taking captured the imagination of Western investors. Other aspects of farmland in the black earth area, such as the large, flat, and square nature of the land plots, also appeared. However, the black earth soil itself predominantly captured the imagination. It featured prominently in accounts of foreign investors as well as in news articles. News articles of farmland investment in the chernozem region sometimes referred to statements by Vasily Dokuchaev - the nineteenth-century founder of Russian earth sciences-who called chernozem 'the tsar of soils' (Dokuchaev 2017, p. 343), which is 'more valuable than gold' (Dokuchaev 1994). Corporate documents and websites widely celebrated the soil, sometimes with pictures of it underlining the story. One Swedish farmland investment company, 'Black Earth Farming', even had the chernozem prominently figuring in its name. The company's website prominently explained the soil's many qualities such as its 'high percentage humus', its 'great depth', and favourable structure for retaining water. ${ }^{8}$ The soil's celebration put excessive attention on the soil, separating it from other relevant factors related to farmland investment, which were subsequently downplayed or forgotten. The focus on the soil-and the ignorance of the land's other features and wider context-is for instance illustrated by Black Earth Farming's director-founder, Mikhael Orlov. In his efforts to attract investors, he embarked on a 'road-show' along Europe's financial centres. Some black earth soil was a consistent prop on these visits; he showed it to potential investors, inviting them to see and feel its quality (Visser 2017; cf. Deutsche Welle 2008). This display clearly illustrates the process of simplification and abstraction through which one particular aspect of a resource is separated-a key step in asset-making (Li 2014; Visser 2017), with investors employing farmland imaginaries which narrow down 'land' to solely 'soil'.

\section{The long history of celebrating the black earth}

The celebration of black earth soil has a long history, which at least goes back to the expansion of the Russian empire to the black earth steppes in the late seventeenth century. Cornelius Cruys, a Dutch naval officer who served Peter the Great during conquests and explorations along the Southern fringe of the empire at the turn of the seventeenth and eighteenth centuries, noted that the 'land is so rich (zhirna), that without manuring the inhabitants receive twice as much for their labours as farmers manage to get in other countries' (Cruys 1824, p. 286). In the eighteenth century, during her tour of newly acquired lands in what is now Southern Russia and Ukraine, Empress Catherine the Great noted: 'where they sow, there is abundance (...). This region is in truth a

\footnotetext{
$\overline{{ }^{8} \text { See footnote } 2 .}$
} 
paradise (...) here, without forcing nature, with little care and less expenditure, there is everything one could want' (Moon 2013, p. 44). Many Western observers who visited the black earth after Cruys likewise noted the soil's immense fertility (Johnson 1843, p. 6; Veber 1795, p. 169).

The depth-or thickness-of the soil, as indicator of its immense fertility, features widely in contemporary and historical accounts of the black earth. Contemporary foreign investors visiting the black earth region have been impressed by how 'amazingly deep' the soil is with its 'prodigiously productive capacity'. 'It's ideal farmland - thick black earth with an extremely thick layer of humus soil' (Winter 2012). The farm company Black Earth Farming, which elaborately discussed the many features of the soil it is named after on its website, specifically stressed that it 'usually has great depth, over $1 \mathrm{~m}$ '. When shown pictures of the thick black soil by an agronomist of the Black Earth Farming company, a farm forum's audience reportedly 'groaned with envy' (ibid; cf. Visser 2017, p. 195).

In the process of simplification that is necessary to turn natural resources into standardized financial assets, depth was a key parameter, probably trumping all other possible soil indicators (organic matter, soil structure, capacity to hold water, etc.). Since the time of Herodotus, visitors to the black earth region have been noting the ' $\operatorname{good}$ deep soil' and its fertility (Moon 2013, p. 44). In the mid-fifteenth century Josaphat Barbar stated that, in the Southern black earth region near Russia's Don delta, local villagers attained yields of up to 1:100 from the fertile soil (Moon 2013, p. 44). In 1767 the proponent of steppe colonization Petr Rychkov spoke of the Russian chernozem in the Orenburg region as 'the good, rich, soft, and thick black-earth' (Sunderland 2004, p. 76). In a book about the economy in the Volga region from 1795 an author celebrates the depth of the 'famous' soil, which

mostly consists of a top layer of 3 to 4 foot [ 1 foot is $30.48 \mathrm{~cm}$ ], but sometimes thelayer of black earth is even several arshin' [old measurement equalling 71.12 cm](Veber 1795, p. 169).

A 1900 report by William Tooke (1900, p. 65), a member of the free economic society of St. Petersburg and the Imperial Academy of Sciences, mentioned that in some places the black earth is up to the 'depth of an ell' $(1.143 \mathrm{~m})$. At the 1889 Paris World exhibition, the award-winning collection of Russian soils curated by Dokuchaev showcased a full cubic meter of chernozem (Shevchenko 2008), aptly visualizing its depth, and was praised as the "standard of fertility' (ibid). A 1900 USDA report concluded that the

\footnotetext{
9 https://www.ft.com/intl/cms/s/0/268d74fc-f8e0-11e1-8d92-00144 feabdc0.html\#axzz3mSYeirp2.
}

depth of Russian chernozem 'is, on average, probably a little greater than that of our prairie soil' (Carleton 1900, p. 8). The celebration of the amazing depth of the black earth soil harboured strong connotations of endless fertility and easy farming. Observations of pre-Soviet visitors to the Russian black earth region that peasants made no effort to fertilize the soil (Moon 2013), carry connotations of the deep soil enabling almost effortless, risk free farming. Western observers were astonished by peasants who did not use manure, but just stockpiled 'enormous piles' beyond their barns (Johnson 1843, p. 6). A visitor in 1795 mentioned that the black earth soil is 'famous, in that it doesn't require new manure' (Veber 1795, p. 169). Even without manure, harvests were so abundant that peasants sometimes left part of the grain unharvested on the fields (Moon 2013, p. 44).

Overall, it is remarkable how the many features of the black earth soil (structure, organic matter, chemical composition, content of minerals, etc.), have so recurrently been simplified into one indicator-namely depth-in farmland imaginaries from the seventeenth century to the present. That this particular indicator was chosen, seems due to: first, it being an easily observable, simple indicator; and second, the seemingly straightforward parallel between sheer depth of the chernozem and its almost endless fertility. This parallel has also been noted in black earth areas elsewhere in the world. ${ }^{10}$

\section{Disappointing farm performance and the ignorance of agro-climatic factors}

The fixation on soil depth, this section will show, has left little room for more cautious perceptions of the benefits and risks of black earth farmland, with attention to climate risk being the biggest casualty. Investors initially paid scant attention to the chernozem region's climate risks and were subsequently caught off guard by the harsh climate, with costly implications for their endeavours. Subsequently, it will be shown that investors could have anticipated these risks had they taken note of the scientific literature. The last sub-section describes how investors look(ed) back at their initial ignorance of climate risk.

\section{Investor accounts of weather risks}

The flipside of the farmland imaginary's focus on soil was that foreign investors paid little attention to weather and agro-ecological risks in the black earth region. The

\footnotetext{
${ }^{10}$ Cronon (1991, p. 98) for instance, states that the deep black soil in the Great Plains 'seemed an almost inexhaustible fund of fertile earth' to the US settlers in the West.
} 
companies did acknowledge that 'poor or unexpected weather conditions' could be a 'significant' risk, and that the growing season in Russia and Ukraine is quite short (BEF 2007, p. 17; Trigon Agri 2007, p. 15). However, these statements were 'general, formulaic and/or obvious in nature' (Kuns et al. 2016, p. 209). The investigated corporate documents did not refer to specific weather data and occupied just a small paragraph in elaborate risk assessments (spanning some $10-15$ pages), predominantly concerned with the political risks (cf. Kuns et al. 2016). The company Trigon Agri (2007, p. 30) even contended that 'the Black Earth region is less susceptible to extreme weather conditions' than Western Europe and the US (cf. Kuns et al. 2016). A Western manager at a Ukrainian farm spoke of 'a farmer's heaven, an (ideal) climate (...) and phenomenally productively land' (sic). ${ }^{11}$ Climate change did not figure prominently in the foreign investors' risk assessments either, as initially scientists and policy makers widely suggested that climate change would be favourable for Russian agriculture.

\section{Weak agricultural performance}

In contrast to the huge potential of the chernozem noted by visitors, the agricultural performance of foreign investors in Russia and Ukraine has frequently been disappointing (cf. Kuns et al. 2016; Visser 2017). The three large stock-listed foreign farm companies, for instance, had many years that ended in red figures, and they faced a sharp drop in their stock valuation. Two of them even felt forced to delist and sell off their farmland holdings, and the third one (formerly Trigon Agri, now Agromino) sold off the Russian part of its landholdings. ${ }^{12}$ Several factors have contributed to dismal farm performance, such as the weak transport and storage infrastructure (particularly in Russia), corruption, and excessive bureaucracy (Winter 2012), diseconomies of scale of the rapidly expanding, finance-driven large farms (Kuns et al. 2016), low payment and motivation of farm workers, and geopolitical tensions following the 2014 conflict between Russia and Ukraine. However, while these political and socio-economic factors have received substantial coverage in the literature, virtually no attention has been given to the subject of this article: how the investment outcome has been influenced by the investors' farmland imaginaries, in particular their ignorance of the harsh climate, that has persistently troubled the region's agriculture.

\footnotetext{
$11 \mathrm{https} / / / \mathrm{www} . \mathrm{ft} . c 0 \mathrm{~m} / \mathrm{intl} / \mathrm{cms} / \mathrm{s} / 0 / 268 \mathrm{~d} 74 \mathrm{fc}-\mathrm{f} 8 \mathrm{e} 0-11 \mathrm{e} 1-8 \mathrm{~d} 92-00144$ feabdc0.html\#axzz3mSYeirp2.

12 The 2014 geopolitical tensions between Russia and Ukraine were a direct trigger, but longstanding economic problems due to underestimated climatic conditions were a more fundamental cause.
}

\section{Soviet farming and adverse climatic conditions}

It is well known that Soviet (and pre-Soviet) agricultural performance was problematic and fluctuated heavily annually. The causes behind this abysmal performance are still being discussed, especially with regard to the Soviet state's role in reinforcing, ignoring or creating bad harvests and famines in the Stalin era. While there is little doubt that variable weather was a significant contributing factor (Wheatcroft 1977; Wheatcroft and Davies 1994; Ioffe and Nefedova 2004; Smith 2014), there is considerable debate regarding the relative importance compared to other factors. More important for the purposes of this article is the finding from in-depth studies that the climate in the heartland of the former Soviet Union (now the black earth region of Russia and Ukraine) has an exceptionally harsh climate with volatile weather in comparison with other major agricultural areas in the world. Clearly, compared with Western Europe, Russia and Ukraine, and their chernozem region, have a much harsher climate with much colder and longer winters and subsequently shorter growing seasons (Dronin and Bellinger 2005 , p. 228). Ioffe and Nefedova (2004, p. 47) note that 'Kursk ( $52^{\circ} \mathrm{N}$. Lat.) located in the middle of Russia's chernozem belt, has colder winters than Helsinki, Finland $\left(61^{\circ}\right.$ N. Lat.)'. The continental climate of the North-American prairies is more similar to the black earth belt of Russia and Ukraine. Yet, as various studies from the early twentieth century onwards have demonstrated, the climate in Russia's chernozem region stands out as harsher even in comparison with the US (Carleton 1900; Field 1968; Wheatcroft 1977; Ioffe and Nefedova 2004; Dronin and Bellinger 2005).

Already from the late nineteenth century onwards, growing numbers of US scientists travelling to Russia, often during missions for the US department of agriculture (USDA) besides observing numerous similarities with the US great plains, noted the harsher conditions in Russia (Moon 2020, pp. 95-96, 112). Carleton's (1900) observations were particularly in-depth (cf. Moon 2020). Similarities such as the highly unequal precipitation throughout the year, the 'excessive heat of midsummer, following intensely cold winters', and the comparatively light snowfall (reducing available moisture in spring), he argued, are 'considerably more pronounced for corresponding portions of the grain belt in Russia' [largely coinciding with the chernozem belt, OV] than the US (Carleton 1900, p. 9). More specifically,

(t)he snow fall (..) is less (..) than on the Great Plains. The rainfall is considerablyless, and the extremes of temperature a little greater (Carleton 1900, p. 9).

In Samara, an important wheat producing region in the eastern, drier part of Russia's black earth, the mean yearly rainfall was $396.4 \mathrm{~mm}$ (15.6 inches), whereas in Bismarck North Dakota, which was already considered as having extremely 
low precipitation for wheat, annual rainfall was $482.6 \mathrm{~mm}$ (15.6 inches) (Carleton 1900, p. 9). The extremes of temperature were also somewhat higher, with Samara's July average at 1.1 degrees higher than in Bismarck, while Samara's yearly temperatures were 0.4 degree less (ibid., pp. 9-10).

During the Soviet period, Field's (1968) study stood out as a rare comparison of the agro-climatic circumstances in the USSR and US. Based on the length of the growing season and the precipitation to evaporation ratio, he found that some 80 percent of Soviet arable land fell within the least productive thermal zone (Field 1968, p. 9). According to Field (ibid., p. 8), the climate in Rostov, one of Russia's top agricultural regions located in the south of the black earth region, is equivalent to South-Dakota, having a relatively marginal position in US agriculture (Ioffe and Nefedova 2004, p. 47). In the post-Soviet era, Ioffe and Nefedova (ibid., p. 48), replicating Field's methodology with improved data, arrived at similar conclusions, and Dronin and Bellinger (2005, p. 8) also stressed Russia's harsher climate. Besides the more extreme climate, as evidenced by annual temperatures and rainfall, Russia's weather is also more volatile year after year. Long-term researcher of Soviet agriculture and the impact of weather, Wheatcroftsum up, weather variability in general $(1977$, p. 3) states:

Because of the complex meteorological factors the weather in the USSR andparticularly in the major agricultural producer areas fluctuates significantly more thanin all other major producer areas. The extent of these fluctuations in annual averagetemperature and rainfall levels is still considerable even when they have beensmoothed by means of a five year moving average.

This volatile weather results from 'the combination of a high continental weather pattern, with the occasional blocking in the seasonal paths of cyclones' (ibid., p. 3), producing 'dry hot east winds' which blow all the way 'from Central Asia across the Volga, Northern Caucasus and the Ukraine' (ibid.). These hot winds from the deserts bring high temperatures and virtually no rainfall, causing serious droughts across the whole chernozem region.

\section{Foreign farm companies' struggle with climate}

As mentioned above, when foreign companies entered the black earth region, beyond some mention of general mismanagement and inefficiency during the Soviet period, they made little or no references to the history of erratic harvests and the essential connections to the harsh and volatile climate. The corporate documents read almost as if the region had no prior agricultural history (cf. Kuns et al. 2016). Yet, when the farm companies started their operations, they soon faced similar climate-related problems as the Soviet farms. Due to the long winters, time slots for activities like sowing, fertilizer application and harvesting are brief, as the weather rapidly changes in the short growing season. The celebrated chernozem can turn into an insurmountable hindrance when the melting snow turns it into mud. As a foreign farm manager in the South of Russia relates (Jewer 2013, n.p.):

Most of the fertiliser is applied in the snow or on frosty ground. (...) This is the only time you can travel; once the snow melts the fields are untravellable for weeks! By the time they will travel it really is too late to apply nitrogen, or else it's too dry to do any good!

A report on Trigon Agri (Agrimoney.com 2015) sums up the long series of weather-related threats that the Nordic farm company faced in just 1 year: inundations in July that 'delayed and hurt' early harvest, followed by the scourge of 'dry and very hot' weather from August to mid-November, with 'no significant rain for about 3 months'. Finally, in October, the company's landholdings experienced 'unseasonal frost' affecting the late harvest, as well as the preparations for the following year's harvest. Interviewed investors admitted that the importance of soil fertility for agricultural performance and overall profitability had been widely overstated (cf. Kuns et al. 2016). One investor said that his company and other Western investors 'were driven by a simplistic view' (cf. Visser 2017, p. 195). Over time, and through a costly process, investors learned that weather conditions, particularly rainfall, were much more critical than initially expected. As an investor interviewed by the author stated (cf. Visser 2017, p. 196):

You can have the best soil in the world, but if the temperature goes up over 35 degrees, and soil temperature goes to 60 degrees, then you have no rain for 4-5 weeks in a row, it will kill your crop.

To sum up, the farm imaginaries' focus on soil, and particularly its depth - a clear example of the separation, simplification, and abstraction that are part of resource and asset making in farmland-appears to have been too narrow. Investors employed imaginaries that themselves lacked 'depth', in terms of the extent of regional knowledge of agro-climatic conditions and histories. In the rare cases where farmland investors took into account precipitation, for instance, they used standardized indicators such as average annual rainfall by province, which did not capture the drastic interregional and seasonal variability. This resulted in a shaky foundation for asset making. Once farm companies and their shareholders, faced with recurrent droughts, recognized that soil fertility was a weak predictor of yields and profits, farmland as a financial asset experienced a sharp erosion in terms of stock valuation and landholding liquidity (Kuns et al. 2016; Visser 2017). 


\section{Explaining ignorance of climate in the land imaginaries}

The centuries-long ignorance of climate in land imaginaries of the black earth raises the question: How could this happen? This question is also an entry point into more theoretical questions of wider relevance beyond the black earth, on ignorance of climate in land imaginaries. The sparse studies that do pay attention to the issue (mostly in passing), suggest that the sidelining of climatic conditions in farmland imaginaries of farmland investors is not exclusive to the black earth region. For instance, during the settlement of the Great Plains in the US farmers widely underestimated the risk of droughts (Worster 1979; Rees 2004). In Australia, known for its difficult climate, high profile contemporary farmland investments failed, just as domestic outside investment projects did earlier, with investors' underestimation of climate risk being an important factor (Magnan 2015). As Uekötter and Lübken $(2014$, p. 3) state 'ignorance about the environment has multiple dimensions and causes', this section attempts to unveil some of these dimensions and causes in relation to farmland imaginaries. The questions it addresses are: Is ignorance in land imaginaries a 'normal' result of the selectivity inherent in the process of resource making? Or is such ignorance related to resource making in frontier areas in particular? Are there other historical or material aspects of the resource that can explain persistent ignorance of climate risk, such as encountered in the black earth?

\section{Resource making and ignorance of climate}

Making natural objects ready for exploitation and/or investment involves a process of selection and simplification ( $\mathrm{Li}$ 2014; Richardson and Weszkalnys 2014; Visser 2017). Not all aspects of a natural object are equally relevant from a business perspective, thus some aspects will be highlighted, and others will only get superficial treatment or will be ignored. However, the climate appears to be very influential regarding the success or failure of the agricultural ventures, so the general simplification that is part and parcel of resource making cannot explain this ignorance. Moreover, the ignorance has been so persistent over the centuries, even in the face of mounting contrary evidence, that additional factors/forces should be taken into consideration.

\section{Frontiers and ignorance of climate}

Literature on resource frontiers provides an additional explanation for more pronounced cases of ignorance. In frontier settings, with a new resource or new regions being subject to resource exploitation, investors' knowledge about the resource or area is 'almost inevitably scarce' (Uekötter and
Lübken 2014, p. 4). Moreover, frontiers normally feature the idea of a first mover advantage which leads to rushed decision making by investors ( $\mathrm{Li} 2014$, p. 595), based on very limited consideration of available knowledge. The chernozem region during the pre-Soviet (and to some extent again during the post-Soviet) period(s) can be characterized as a resource frontier, as the Tsarist empire's colonization of the steppes in the seventeenth and eighteenth centuries replaced extensive nomadic husbandry with settler agriculture. ${ }^{13}$ During the nineteenth and early twentieth century, the expansion of railroads and the rise of the black earth region as a global wheat exporter meant an intensification of the resource frontier. Even before the advent of the Soviet Union in 1917, practically the whole black earth area of Russia and Ukraine was ploughed up (Ioffe and Nefedova 1998). In the post-Soviet era, the idea of the black earth region as a frontier of international farmland investment resurfaced in popular and academic accounts (Kramer 2008; Visser et al. 2012; Winter 2012). This was reinforced by the availability of vast surfaces of supposedly 'pristine, untouched' farmland (Kramer 2008) that had been abandoned during the deep crisis of the 1990s (Visser et al. 2012) and the rapid re-insertion of the region's agriculture in global markets.

During the pre-Soviet frontier period, newcomers faced a dearth of knowledge on agro-climatic conditions, as agriculture on the black earth had no long history and soil science and climate knowledge were still in their infancy. ${ }^{14}$ Ignorance resulted in no small way from the absence of information. During the land rush frontier of the 2000s, much more scientific knowledge about agro-climatic factors and tools to measure agro-climatic conditions existed (such as moisture sensors, data from weather stations, etc.). However, such (contemporary) knowledge did not significantly influence the farm operations, as the farmland investors were driven by a typical frontier mentality focussed on quickly amassing as much cheap resources (farmland) as possible before land prices jumped up. The executive director of one of the Nordic companies complained that his advice against the purchase of a large farm-due to its poor agro-climatic features - was ignored by the board; instead, the vision of acquiring as much black earth farmland as possible prevailed (Kuns et al. 2016). The strategy of rushed land acquisition, virtually without taking into account agro-climatic evidence, was reinforced by the fact that the top management levels of the large farm companies often consisted of people with a background in finance, real estate and other sectors, rather

\footnotetext{
13 And part of the nineteenth century.

14 Although soil science, particularly in Russia, was emerging (Moon 2013, 2020).
} 
than agribusiness. ${ }^{15}$ Amongst the three Nordic farm companies listed on the stock exchange that operated in Russia and Ukraine, none featured members with agricultural experience on their boards during the first years of operation (Kuns et al. 2016).

Foreign companies had some awareness of weather risks, but thought that they could simply be mitigated. They dealt with weather and climate change risks through so-called 'weather hedging', which is the geographic dispersion of land holdings in a way that bad weather in one region (such as a drought or a hail storm) can be offset by more favourable weather on land holdings in another region (Trigon Agri 2011, p. 7). The idea was that that they had little to worry about regarding local agro-ecological circumstances because natural risks even out over the geographically dispersed landholdings. However, the ideas that the climate in the chernozem zone was somewhat mild, predictable, and that it harboured sufficient intra-regional variation to allow weather hedging, were all contrary to scientific evidence. As discussed earlier, numerous studies from the early nineteenth century onwards have demonstrated the huge risks of drought in the area, and have convincingly argued that the climate is significantly harsher than in the US agricultural heartland. Wheatcroft (1977) for instance, has shown that most droughts simultaneously affected almost the whole chernozem belt over many thousands of kilometres from Western Ukraine far into European Russia, unsettling the (convenient) idea of weather hedging. However, it was not only rushed corporate decision-making typical for resource frontiers that hampered more balanced assessments based on inclusion of climate knowledge. As will be argued below, investors' oversight was the result of a much broader, persistent ignorance of climate in Western science and policy advice on post-Soviet agriculture.

\section{Ideology and ignorance of climate}

Investors' ignorance of a long series of first-hand experiences and scientific evidence on climate in the chernozem zone, should be understood within the context of a much wider, longstanding ignorance of such knowledge within domestic and Western society, and among policy advisors and academics. Multiple factors seem to have contributed to investors' ignorance.

First, ideological preoccupations have led to a societywide forgetting of a body of research on climate, which has hampered a relatively unbiased assessment. Biases

\footnotetext{
15 Scientifically informed perspectives can also be problematic. See Davis (2007) on how flawed French scientific ideas of previous deforestation and desertification in North Africa misinformed colonial agrarian endeavors.
}

have existed both in scholarly and policy studies, as well as amongst the investor community. In much of the Western literature, the failures of Soviet agriculture have been attributed to political factors (such as the inefficiencies of a top-down command economy, weak labour motivation in collective farms et cetera), whereas climatic factors have been denounced as mere excuses of the Soviet regime (Ioffe and Nefedova 2004, p. 47; Smith 2014). The passive 'making' of ignorance (ignorance as a 'selective choice' or 'lost realm' in the words of Proctor 2008, p. 4) has taken place. Pre-soviet studies such as by Carleton and others have been forgotten, and new studies on climatic factors were virtually unknown during the Soviet period (an exception being Field 1968). The Soviet regime itself, with its strong belief in engineering nature (Dronin and Bellinger 2005) had little tolerance for kolkhoz chairmen referring to climate to explain failures. As Smith (2014, p. 61), notes:

Crucially, the Soviet state overlooked its primary adversary, which was natural, not cultural.[It] approached Soviet rural areas as socially backward places that needed order and discipline in order to become modern (...).

However, agriculture was 'dominated by austere natural realities far more than by backward social mentalities or revolutionary political spirits' (ibid.). Overall, while there was substantial literature on climate risks in the black earth region, such literature has largely been forgotten, through what Proctor (2008, p. 6) called ignorance as a 'selective choice' or 'passive construct'.

Second, the mainstream discourse that depicted the failures of Soviet agriculture as solely attributable to political factors have fitted the perceptions and interests of foreign farmland investors. This discourse has helped to frame a Russian agriculture freed from socialist bureaucracy as very promising. Investors' observations of widely abandoned lands (AlpcotAgro 2008) have also been conducive to framing of Russian agriculture as a clean sleet. A settler/ colonizer ideology negatively viewing indigenous engagements with nature also led newcomers in other settings to grossly ignore weather risks. US settlers in the West, for instance, saw native Americans' pastoral and farming practices of coping with drought as primitive and irrelevant (Moon 2020). In North Africa, French colonial plantations suffered dramatically from shallow farmland imaginaries, which assumed that the arid farmlands were the result of overgrazing and deforestation by the local population, rather than climatic conditions (Davis 2007).

\section{Fabricating climate ignorance?}

The question arises as to what extent farmland companies and brokers were aware of the climatic risks, yet actively 
ignored and/or downplayed them, or even fabricated evidence, with ignorance being an 'active construct' and 'strategic ploy' (Proctor 2008, p. 8). Studies on the US Great Plains feature ample examples of boosters actively suppressing unfavourable information about farmland, or even intentionally creating false, over-optimistic information (see Fairbairn et al. this issue) on contemporary US investors silencing climate risks. The Western booster Josiah Gregg, for instance, effused in 1844 that the extreme cultivation of farmland might contribute to increased rainfall (Rees 2004, p. 82; cf. Uekötter and Lübken 2014, p. 5). This 'theory' was then initially taken on by a scientist, and many prospective farmers flocked to the West. Knowledge that refuted the boosters' stories was actively suppressed. An official at the US geological society who actively warned against these accounts that underestimated the climate risks, was forced out of his post by boosters (Rees 2004, pp. 83-84). Extensive study of company documents and in-depth interviews with investors in Russian farmland did not generate indications of intentional silencing of climate risks. Ignorance is predominantly a 'passive construct' (Proctor 2008, p. 6) by investors, on top of a much longer history of passive ignorance in Cold War-era academics and policy.

\section{The senses, knowledge and ignorance of climate}

That ideological stances could relatively easily turn large bodies of literature on climate in the black earth region into 'a lost realm' (Proctor 2008, p.4) was facilitated by the difficulties of grasping the climate properly. The parallel $\mathrm{cel}$ ebration of soil and ignorance of climate is also a result of the very different sensory capabilities to garner knowledge regarding these two issues. Interesting in this respect is Kerans' (2001, pp. 27-28) description of how imaginary firsttime travellers to Russia's black earth region Tambov in the nineteenth century would have experienced the countryside:

If the travellers had never before visited the region, the soil below the flora would likely catch their attention. Wherever the ground was laid bare by recent tillage, its dark brown hue, sometimes truly verging on the black, betrayed the fertility of the land'. Moving a substantial distance along in a southern or easterly direction, an observant traveller would note that (...) water sources became sparser. If he took the initiative to inquire of the locals along the way, he would learn that the rain fell less consistently .... Even further south-east in the province, 'the monotony of the landscape was joined to the unpredictability of precipitation. The quality of the soil remained superlative, but the threat of drought could never be far from the farmer's mind (Kerans 2001, p. 28).
This description alludes to an important difference in sensory capabilities in assessing soil versus climate. The quality of the soil, especially if laid bare, can directly be assessed visually. In contrast, the amount of rainfall (and the risk of drought) has to be assessed more indirectly from attentively observing the diminishing presence of water sources, and actively asking farmers about it. Further, the relative absence of something (rainfall) is less easily noticed than something permanently present like soil of which manifold parameters (like colour, depth, and structure) can be assessed at any moment in time. Sight has been the predominant mode to perceive landscapes, and the world at large, especially in European (including Russian) society where it concerns knowledge rather than emotions. 'There is a profound connection forged over half a millennium between the modern usage of landscape (...) and the exercise of sight or vision as a principal means of associating that space with human concerns' (Cosgrove 2003, p. 249). Through pictures and later photographs visual observations can be communicated more easily than information gathered through senses like smell or taste, and swiftly becomes accepted knowledge. As mentioned earlier, various farmland companies operating in the black earth region featured images of the black soil as evocative clues of bountiful farming conditions.

For further examination beyond sight, the soil can be touched, generating further clues about the structure of the soil, and one can smell it. This also allows somewhat more emotional clues connected with touch, smell, and even taste that reinforces positive connections with the soil. Earlier on it was mentioned how a contemporary farmland investor took the soil with him on an investment road tour for potential investors to see, touch and smell. Ioffe and Nefedova (1998, p. 196) describe how Western scientists visiting the Soviet Union, demanded to get out of their busses to touch the black earth soil and 'kneaded the fat damp lumps of soil in their hands' momentarily impressed by the fertility of the farmland. Assessing climate is difficult, as weather does not present itself in a relatively fixed state like soil which can be easily spotted by sight, recorded and transmitted as an image. Weather can vary from day to day and requires combining a more elusive set of indicators captured by various senses and tools in order to distil a weather pattern (climate). Variability becomes a formidable obstacle to assessing climate when climate is strongly volatile over the years, or even drastically varies from decade to decade. ${ }^{16}$ Examples from the US West are illuminating in this respect. During the whole period 1878-1887 the entire Great Plains area west of the ninety-eighth meridian experienced extraordinary bountiful rainfall (Rees 2004 , p. 84). The highly atypical rainfall lured many farmers to settle in the area. It tricked farmers

$\overline{16}$ This is even without anthropogenic climate change. 
into believing that this was the normal climate in the region and caused a proliferation of optimistic beliefs (for instance that the newly constructed railways and electricity lines or intensive ploughing generated increased rainfall). In Russia, such yearly volatility is even starker (Dronin and Bellinger 2005, pp. 5-6). Wheatcroft and Davies (1994, p. 45) has argued that the agricultural boom in early twentieth century Tsarist Russia, widely attributed to politics (for example the Stolypin land reforms), was in fact largely caused by a long period of exceptionally favourable weather. The difficulties in agriculture in the 1920s-1930s, while certainly triggered by erratic policies, were substantially reinforced by successive droughts (Wheatcroft 1977). To sum up, weather variability in general, and the stark volatility of climate over years or decades, can easily deceive scientists who have access to abundant data, let alone newcomers who have to judge the situation on the spot, based on their own senses.

\section{Conclusions}

The environmental history approach to land investment and transformations, as applied here, shows the striking persistence of land imaginaries, even when their material foundations are shaky. This article has demonstrated that investors' celebration of the soil, and particularly its depth, has a centuries-long history. This celebration has had considerable downsides as it has led to downplaying or ignoring other factors-notably climatic risk-with important repercussions for the viability of the farm operations. The investigation of farmland imaginaries and investment operations in the black earth region, and the examination of similar tendencies elsewhere in the world, suggest that the historical dimension of land imaginaries deserves more attention. In particular, the often detrimental ignorance or underestimation of climate is striking. This article followed up on the call to pay more attention to the historical dimension of farmland investment (Edelman and León 2013; Ouma 2016) and did so by bringing in its largely unexplored environmental history. Despite the appearance of sophistication that often surrounds contemporary transnational farmland investments and imaginaries, they might be haunted by strikingly similar misunderstandings of the agro-climatic context of farmland, as their historic predecessors. The selectivity and simplification of resource making in general, and in frontiers especially; the difficulty of assessing climate, especially when very volatile, first-hand, based on our senses; and widely shared ideological biases that led to passive ignorance of Soviet-era scientific evidence; these factors together brought about the staggering ignorance of climatic risks by contemporary farmland investors in the black earth.

The blind spots in the imaginaries employed by farmland investors are replicated by academic studies on land investment and land transformations worldwide. While various dimensions of land (especially property and territory) have received a lot of attention, the climatic conditions connected to farmland investments and other land transformation have been side-lined. Obviously, there is attention for climate change as a global context of land investments, but when climate presents itself as a-seemingly-more permanent, somewhat predictable condition, it evaporates as an analytical category. This suggests that climate moves to the margins of human perceptions unless changes are sudden and dramatic and, above all, 'abnormal'. It reminds us of Hirsch's (1995) argument that landscape, and natural environment, is best seen as a background to other things. It is commonly perceived as a realm of potential, the locus of the way things might be, rather than of present, grounded reality (ibid.). The land imaginaries concept-especially when combined with a historical perspective and recent insights on ignorance (Proctor 2008) — can help to direct attention to the selectivity, ignorance, and implicitness in human perceptions and representations regarding land transformations and climate and their tremendous socio-economic and environmental implications.

Acknowledgements This article benefitted greatly from comments by Sarah Ruth Sippel and the anonymous referees. Further, I am grateful for insightful comments by Tanya Richardson, Daniel Münster and others at the Land Imaginaries workshop at Leipzig University, feedback by David Moon, Judith Pallot and Brian Kuns at a BASEES panel in Cambridge, and comments by James Scott, Keri Lambert, and others at the agrarian studies colloquium at Yale University. The research was enabled by an European Research Council (ERC) grant (LANDGRABRU, StG 313871).

Open Access This article is licensed under a Creative Commons Attribution 4.0 International License, which permits use, sharing, adaptation, distribution and reproduction in any medium or format, as long as you give appropriate credit to the original author(s) and the source, provide a link to the Creative Commons licence, and indicate if changes were made. The images or other third party material in this article are included in the article's Creative Commons licence, unless indicated otherwise in a credit line to the material. If material is not included in the article's Creative Commons licence and your intended use is not permitted by statutory regulation or exceeds the permitted use, you will need to obtain permission directly from the copyright holder. To view a copy of this licence, visit http://creativecommons.org/licenses/by/4.0/.

\section{References}

AlpcotAgro. 2008. Annual report 2007. Stockholm. https://www. agrokultura.com/financial\%2520reports.aspx. Accessed January 152014.

Agrimoney.com. 2015. Trigon Agri counts cost of Ukraine drought. Russia land deal. Agrimoney.com. https://www.agrimoney.com/ news/trigon-agri-counts-cost-of-ukraine-drought-russia-landd eale9056.html. Accessed November 302015.

BEF (Black Earth Farming). 2007. Invitation to subscribe for depository receipts in Black Earth Farming LTD. Stockholm. https:// 
files.shareholder.com/downloads/ABEA-4N3O94/3863033178 x0x518759/CFB7FA53-345F-4F98-AD65-ACA361379E5F/ BEF_Int_Prospectus_Non_US.pdf. Accessed December 152014.

Bennett, J. 2010. Vibrant matter: A political ecology of things. Durham: Duke University Press.

Bridge, G. 2009. Material worlds: Natural resources, resource geography and the material economy. Geography Compass 3 (3): 1217-1244.

Carleton, M.A. 1900. Russian cereals. Adapted for cultivation in the United States. USDA division of botany. Bulletin 23. Washington: Government Printing Office.

Cosgrove, D. 2003. Landscape and the European sense of sight-eyeing nature. In Handbook of cultural geography, ed. K. Anderson, M. Domosh, S. Pile, and N. Thrift, 249-268. London: Sage.

Cronon, W. 1991. Nature's metropolis. Chicago and the Great West. New York: W.W. Norton and Company.

Cruys, C. 1824. 'O nravakh i obyknoveniyakh Donskikh Kazakov, v kontse XVII veka' [translated from Dutch], Severnyi arkhiv 11: 283-296.

Davis, D.K. 2007. Resurrecting the granary of Rome: Environmental history and French colonial expansion in North Africa. Athens, $\mathrm{OH}$ : Ohio University Press.

Davis, D.K. 2011. Imperialism, orientalism, and the environment in the Middle East. In Environmental imaginaries of the Middle East and North Africa, ed. D.K. Davis and E. Burke III, 1-22. Athens, Ohio: Ohio University Press.

Deutsche, W. 2008. Made in Germany: German farmers discover the Ukraine. Deutsche Welle-TV. https://www.youtube.com/watch ?v=TQ1GQxxFHg4. Accessed August 152016.

Dokuchaev, V.V. 1994. Dorozhe zolota Russkii chernozem. Moscow: MGU Press.

Dokuchaev, V.V. 2017. Lektsii o pochvovedenii. Izbrannye trudi. Moscow: Yurait.

Dronin, N.M., and E.G. Bellinger. 2005. Climate dependence and food problems in Russia 1900-1990: The interaction of climate and agricultural policy and their effect on food problems. Budapest, New York: CEU University Press.

Edelman, M., and A. León. 2013. Cycles of land grabbing in Central America: An argument for history and a case study in the Bajo Aguán, Honduras. Third World Quarterly 34 (9): 1697-1722.

Field, N.C. 1968. Environmental quality and land productivity: A comparison of the agricultural land base of the USSR and North America. Canadian Geographer 7 (1): 1-14.

Goldstein, J.E. 2016. Knowing the subterranean: Land grabbing, oil palm, and divergent expertise in Indonesia's peat soil. Environment and Planning A 48 (4): 754-770.

Hirsch, E. 1995. Introduction: Landscape-between place and space. In The anthropology of landscape: Perspectives on place and space, ed. E. Hirsch and M. O'Hanlon, 1-30. Oxford: Oxford University Press.

Ioffe, G., and T. Nefedova. 2004. Marginal farmland in European Russia. Eurasian Geography and Economics 45 (1): 45-59.

Ioffe, G., and T. Nefedova. 1998. Continuity and change in rural Russia. A geographical perspective. Boulder: Westview Press.

Jasanoff, S. 2015. Imagined and invented worlds. In Dreamscapes of modernity: Sociotechnical imaginaries and the fabrication of power, ed. S. Jasanoff and S.-H. Kim, 321-341. Chicago: University of Chicago Press.

Jewer, R. 2013. Farming in Russia. Farmers weekly. https://www. fwi.co.uk/machinery/farming-in-russia.htm. Accessed May 2016.

Johnson, C. 1843. The manures adapted for different soils. The British Farmer's Magazine 7 (25): 5-25.

Kerans, D. 2001. Mind and labor on the farm in Black-Earth Russia, 1861-1914. Budapest, New York: CEU Press.

Kramer, A. E. 2008. Russia's collective farms: Hot capitalist property. New York Times. 30 August. http://www.nytimes.com/2008/08/31/ business/worldbusiness/31food.html?pagewanted=print\&_r=0. Accessed 10 Oct 2020.

Kuns, B., O. Visser, and A. Wästfelt. 2016. The stock market and the steppe: The challenges faced by stock-market financed, Nordic farming ventures in Russia and Ukraine. Journal of Rural Studies 45: 199-217.

Larder, N., S.R. Sippel, and N. Argent. 2017. The redefined role of finance in Australian agriculture. Australian Geographer 49 (3): $397-418$.

Li, T.M. 2014. What is land? Assembling a resource for global investment. Transactions of the Institute of British Geographers 39 (4): 589-602.

Magnan, A. 2015. The financialisation of agri-food in Canada and Australia: Corporate farmland and farm ownership in the grain and oilseed sector. Journal of Rural Studies 41: 1-12.

Moon, D. 2013. The plough that broke the steppes. Agriculture and environment on Russia's grasslands, 1700-1914. Oxford: Oxford University Press.

Moon, D. 2020. The American steppes. The unexpected Russian roots of Great Plains agriculture, 1870s-1930s. Oxford: Cambridge University Press.

Ouma, S. 2016. From financialization to operations of capital: Historicizing and disentangling the finance-farmland-nexus. Geoforum 72: 82-93.

Proctor, R.N. 2008. Agnotology: A missing term to describe the cultural production of ignorance (and its study). In Agnotology: The making and unmaking of ignorance, ed. R.N. Proctor and L. Schiebinger, 1-36. Redwood City, CA: Stanford University Press.

Rees, A. 2004. The Great Plains region. Westport, London: Greenwood Press.

Richardson, T., and G. Weszkalnys. 2014. Introduction: Resource materialities. Anthropological Quarterly 87 (1): 5-30.

Shevchenko, V.E. 2008. Slovo o Russkomchernozeme, iliktospasettsaryapochv? Vestnik OrelGAY 1: 28-29.

Sippel, S.R., and O. Visser. 2020. Introduction to Symposium: Reimagining land: Materiality, affect and the uneven trajectories of land transformation. Agriculture and Human Values. https://doi. org/10.1007/s10460-020-10152-3.

Smith, J.L. 2014. Works in progress. Plans and realities on Soviet farms, 1930-1963. New Haven: Yale University Press.

Sunderland, W. 2004. Taming the wild field. Colonization and Empire on the Russian Steppe. Ithaca: Cornell University Press.

The Local. 2009. Swedish farm snaps up Russian farmland. 12 October, AFP/The Local.se. https://www.thelocal.se/20091012/22606 . Accessed October 152016.

Tooke, W.F.R.S. 1800. View of the Russian Empire during the reign of Catharine the second and to the close of the eighteenth century, 2nd ed, vol. 1. London: T.N. Longman and O. Rees, Paternoster.

Trigon Agri. 2007. Company description in connection with the admission to trading on First North. https://www.trigonagri.com/wpcontent/uploads/2011/07/Trigon_Agri_Company_Descriptio n_2007.pdf. Accessed December 152014.

Trigon Agri. 2011. Annual report 2010. https://www.trigonagri.com/ investor-relations/financial-reports/annua-reports/. Accessed January 152014 .

Uekötter, F., and U. Lübken. 2014. The social functions of ignorance. In Managing the unknown. Essays on environmental ignorance, ed. F. Uekötter and U. Lübken, 1-11. Berghahn: London.

Veber, I.I. (1795). Primechaniya o razlichnykh predmetakh khozyaistva v Ekaterinoslavskom Namestnichestve. Trudy Vol'nogo Ekonomicheskogo Obshchestva 50: 169-201.

Visser, O. 2017. Running out of farmland? Investment discourses, unstable land values and the sluggishness of asset making. Agriculture and Human Values 34 (1): 185-198. 
Visser, O., and M. Spoor. 2011. Land grabbing in post-Soviet Eurasia: The world's largest agricultural land reserves at stake. The Journal of Peasant Studies 38: 299-323.

Visser, O., N. Mamonova, and M. Spoor. 2012. Oligarchs, megafarms, and land reserves: Understanding land grabbing in post-Soviet Russia. The Journal of Peasant Studies 39 (3-4): 899-931.

Wheatcroft, S.G. 1977. The significance of climatic and weather change on Soviet agriculture (with particular reference to the 1920s and 1930s). CREES-SIP discussion paper no 11. Birmingham: University of Birmingham.

Wheatcroft, S.G., and R.W. Davies. 1994. Agriculture. In The economic transformation of the Soviet Union, 1913-1945, ed. R.W. Davies, M. Harrison, and S.G. Wheatcroft, 106-130. Cambridge, New York: Cambridge University Press.

White, B., S.M. Borras Jr., R. Hall, I. Scoones, and W. Wolford. 2012. The new enclosures: Critical perspectives on corporate land deals. The Journal of Peasant Studies 39 (3-4): 619-647.

Winter, S. 2012. Pig and protection money: German farmers seek their fortunes in Russia, Der Spiegel International Online. https://www. spiegel.de/international/europe/pigs-and-protection-money-germa n-farmers-seek-their-fortunes-in-russia-a-808377.html. Accessed September 12016

Wolford, W., S.M. Borras Jr., R. Hall, I. Scoones, and B. White. 2013. Governing global land deals: The role of the state in the rush for land. Development and Change 44 (2): 189-210.

Worster, D. 1977. Nature's economy. A study of ecological ideals. Cambridge: Cambridge University Press.
Worster, D. 1979. Dust bowl: The southern plains in the 1930s. Oxford: Oxford University Press.

Publisher's Note Springer Nature remains neutral with regard to jurisdictional claims in published maps and institutional affiliations.

Oane Visser is Associate Professor at the International Institute of Social Studies (ISS) in The Hague, the Netherlands, and a fellow of the UK-based Independent Social Research Foundation. He has been visiting scholar at University of Oxford, City University New York, Cornell University, and University of Toronto. His research focuses on farmland investment, large-scale farms, digital farming, interactions between small and large farms, and rural movements, particularly in the EU (the Netherlands, Romania), Russia and Ukraine. European Research Council (ERC) laureate Visser is the coordinator of the Eurasian Agrofood and Land initiative (EURAL), and an editor of Focaal-Journal of Global and Historical Anthropology. Visser (co-) edited five special issues, including two on financialization of agriculture (in Agriculture and Human Values, and Journal of Agrarian Change). He published articles in, amongst others, Journal of Rural Studies, Journal of Peasant Studies, Globalizations, Focaal and European Journal of Sociology. 